\title{
Efficacy of Whole Body Vibration on Strength of Calf and Quadriceps Muscles Post Burn
}

\author{
MOHAMMED R. GOMAH, M.Sc.*; ASHRAF H. MOHAMMED, Ph.D.**; \\ HEBA M. MOHAMADY, Ph.D.** and AYMAN A. MOHAMED, M.D.*** \\ The Department of Physical Therapy for Surgery, Faculty of Physical Therapy, MUST University*, \\ The Department of Physical Therapy for Surgery, Faculty of Physical Therapy, Cairo University** and \\ The Department of General \& Plastic Surgery, Faculty of Medicine, Fayoum University***
}

\begin{abstract}
Background: This study was conducted to evaluate the efficacy of whole-body vibration on strength of calf and quadriceps muscles post burn.

Patients and Methods: Thirty patients (male and female) had second degree burn of lower limb with surface area about (20-35\%) suffering from weakness of quadriceps and calf muscles. Their ages ranged between (20-35) years were participated in this study. The study conducted during the period between March and July (2017) at Makka Hospital and Al-Nada Hospital.

They were assigned randomly into two Groups (A and B) equal in number: Group (A) Fifteen patients had received vibration training on vibration platform plus traditional physical therapy program (eight weeks, three times a week). Group (B) fifteen patients had received the same traditional physical therapy program only.

Evaluation: Evaluations of both Groups (A and B) were done before starting the treatment and at the end of study after eight weeks using hand held dynamometer and manual muscle test.

Treatment: Started immediately post wound closure. This study showed a statistically significant increase in calf and quadriceps muscle strength after eight weeks of receiving whole body vibration in addition to home based physical therapy program, compared with Group B who received traditional physical therapy program only.

Results: Comparison between both Groups (A and B) before starting the study revealed that there was a statistically nonsignificant difference in calf and quadriceps muscle force between them. At the end of the study, there was a significant increase in the muscle force in the study group (Group A) compared with control groups (Group B).

Conclusion: Participation in Whole Body Vibration (WBV) program resulted in a greater improvement in quadriceps and calf muscle strength in adults with healed thermal burn compared to base line values; a WBV program is an effective for strength gain in rehabilitation of burned patients.
\end{abstract}

Correspondence to: Dr. Mohammed R. Gomah,

The Department of Physical Therapy for Surgery, Faculty of Physical Therapy, MUST University
Key Words: Whole body vibration - Thermal burn - Hand held dynamometer-Manual muscle test.

\section{Introduction}

BURN is a type of injury to flesh caused by heat, electricity, chemicals, light, radiation or friction. Most burns only affect the skin (epidermal tissue and dermis). Rarely, deeper tissues, such as muscles, bone, and blood vessels can also be injured [1].

Burn trauma leads to damage of muscle, nerves vascular, dermal and epidermal tissue with subsequent pain; also burns result in severe psychological and emotional distress because of long-term hospitalization, scarring and deformity. Low physical work capacity and muscle strength are major obstacles in allowing the burn victim to perform activities of daily living [2].

The degree of a burn is determined by the percentage of Total Body Surface Area (TBSA) affected and TBSA $>30 \%$ is considered major (severe) burn [3]. Burn injury involves multiple organ system dysfunction and sepsis, creating a complex network of metabolic interactions, which include inflammation, immobilization and stress [4]

Whole Body Vibration Training (WBVT) can be described as exercising on a platform with an oscillating motion [5].

Whole Body Vibration (WBV) is a newly developed neuromuscular training method, in which vibrations of various frequencies are provided to mechanically stimulate the receptors in the body such as muscle spindles [6]. 
Whole Body Vibration Training (WBVT) elicits a biological adaptation that is connected to the neural potentiation effect. In this effect the proprioceptive pathways are strongly stimulated by the vibration which results in reflexive muscle contractions. Although WBV combined with resistance training is becoming increasingly popular in various training recommendations, there is still an ongoing debate in literature, whether there are additional effects of WBV on muscle fitness and muscle performance in comparison to conventional exercise [7].

\section{Subjects and Methods}

The study conducted during the period between March and July (2017) at Makka Hospital and AlNada Hospital in Fayoum.

Subjects: Thirty patients who had a burn in the lower limb and suffered from a weakness of quadriceps and calf muscles post burn. They were selected from Makka Hospital and Al-Nada Hospital. Patients were assigned randomly into two groups of equal numbers, (Group A and Group B).

Inclusive criteria: All patients participated in this study were of both sex, age ranged between 20 and 35 years, had 2 nd degree degree of thermal burn of lower limb with (20-35\%) surface area of burn, suffered from weakness of quadriceps and calf muscles post burn and have sufficient cognition and education enough to understand the requirements of the study.

Exclusive criteria: All patients who diagnosed with acute rheumatoid arthritis, joint replacement within the past year, history of traumatic spine within the past six months, prosthesis, recent fracture or bone injury.

Equipment: The study equipment were divided into two different categories, measuring and therapeutic equipment.

Measuring equipment: Evaluation the strength of quadriceps and calf muscles using hand held dynamometer and manual muscle test.

Treatment equipment: Whole body vibration apparatus (super fit massage, PS-CFM 014, made in China). The frequency of vibration was set at $30 \mathrm{~Hz}$, which produced a peak-to-peak amplitude ranging from 4 to $7 \mathrm{~mm}$.

Procedure of application: All participants were informed about the nature and the effect of the treatment and measurement device. The patients were instructed to report any side effects during the treatment sessions. Treatment time of the present study was given in the period of 8 weeks.

1- Group A (study group): 15 patients had a weakness of quadriceps and calf muscles. They received vibration training on vibration platform plus traditional physical therapy program 3 sessions per week for total period of 8 weeks. The total duration of the WBV training stimulus was $10 \mathrm{~min}$ in first week and progress gradually to $25 \mathrm{~min}$ in the $8^{\text {th }}$ week.

2- Group B (control group): 15 patients had a weakness of quadriceps and calf muscles. They received the same traditional physical therapy program only.

- All participants in this study follow exercise guidelines prescribed the exercise performed at home (three days/week) regarding the intensity, type and duration to control any variation between groups and instructions about there was no exercise done on the rest of the week.

Ethical consideration: Confidentiality was assured by signing the consent form and respect to all patients was ascertained through explaining the objectives of the study and its benefits. The study was approved by Ethical Committee of Faculty of Physical Therapy, Cairo University. (P.T.REC/012/001000).

\section{Results}

As observed in, the mean \pm SD age of Group A was $26.06 \pm 4.46$ years, with maximum value of 35 years and minimum value of 20 years while the mean \pm SD age of Group B was $27.6 \pm 4.73$ years, with maximum value of 35 years and minimum value of 20 years. There was no significant difference between both groups in the mean age values $(p=0.36)$ (Table 1).

Table (1): Comparison of mean age values between Group A and $\mathrm{B}$.

\begin{tabular}{llll}
\hline & & Group A & Group B \\
\hline \multirow{2}{*}{ X \pm SD } & $26.06 \pm 4.46$ & $27.6 \pm 4.73$ \\
& Minimum & 20 & 20 \\
& Maximum & 35 & 35 \\
& MD & \multicolumn{2}{c}{-1.54} \\
& $t$-value & \multicolumn{2}{c}{-0.91} \\
& $p$-value & \multicolumn{2}{c}{0.36} \\
& Significance & \multicolumn{2}{c}{ NS } \\
\hline X & : Mean. & \multicolumn{2}{c}{ SD \pm : Standard Deviation. } \\
MD & : Mean Difference. & t-value : Unpaired $t$-value. \\
$p$-value & : Probability value. & NS : Non Significant.
\end{tabular}


The sex distribution of Group A was revealed that there were 7 females with reported percentage of $47 \%$ and 8 males with reported percentage of $53 \%$. The sex distribution of Group B revealed that there were 5 females with reported percentage of $33 \%$ and 10 males with reported percentage of $67 \%$ as shown in (Table 2).

Table (2): The frequency distribution of sex in Group A and B.

\begin{tabular}{lcclcc}
\hline & \multicolumn{2}{c}{ Group A } & & \multicolumn{2}{c}{ Group B } \\
\cline { 2 - 3 } \cline { 5 - 6 } & Females & Males & & Females & Males \\
\hline No. & $7(47 \%)$ & $8(53 \%)$ & & $5(33 \%)$ & $10(67 \%)$ \\
\hline Total & $15(100 \%)$ & & \multicolumn{2}{c}{$15(100 \%)$} \\
\hline
\end{tabular}

The mean \pm SD calf muscle force pre treatment of Group A was $20.48 \pm 1.86 \mathrm{~kg}$ and that post treatment was $29.6 \pm 2.39 \mathrm{~kg}$. The mean difference between pre and post-treatment was $-9.12 \mathrm{~kg}$ and the percent of improvement was $44.53 \%$. There was a significant increase in the calf muscle force in the Group A post-treatment compared with pretreatment $(p=0.0001)$ (Table 3$)$.

The mean \pm SD quadriceps muscle force pretreatment of Group A was $19.96 \pm 2.1 \mathrm{~kg}$ and that post-treatment was $29.7 \pm 1.79 \mathrm{~kg}$. The mean difference between pre and post-treatment was $-9.74 \mathrm{~kg}$ and the percent of improvement was $48.79 \%$. There was a significant increase in the quadriceps muscle force in the Group A post-treatment compared with pre-treatment $(p=0.0001)$ (Table 3$)$.

The mean \pm SD calf muscle force pre-treatment of Group B was $21.01 \pm 2.78 \mathrm{~kg}$ and that posttreatment was $25.78 \pm 2.59 \mathrm{~kg}$. The mean difference between pre and post-treatment was $-4.77 \mathrm{~kg}$ and the percent of improvement was $22.7 \%$. There was a significant increase in the calf muscle force in the Group B post-treatment compared with pretreatment $(p=0.0001)$ (Table 4).

The mean \pm SD quadriceps muscle force pretreatment of Group B was $20.25 \pm 2.54 \mathrm{~kg}$ and that post-treatment was $26.18 \pm 3.39 \mathrm{~kg}$. The mean difference between pre and post-treatment was -5.93 $\mathrm{kg}$ and the percent of improvement was $29.28 \%$. There was a significant increase in the quadriceps muscle force in the Group B post-treatment compared with pre-treatment $(p=0.0001)$ (Table 4$)$.

The mean \pm SD calf muscle force pre-treatment of Group A was $20.48 \pm 1.86 \mathrm{~kg}$ and that of Group $\mathrm{B}$ was $21.01 \pm 2.78 \mathrm{~kg}$. The mean difference between both groups was $-0.53 \mathrm{~kg}$. There was no significant difference in the calf muscle force between Group $\mathrm{A}$ and B pre-treatment $(p=0.68)$ (Table 5).

The mean \pm SD quadriceps muscle force pretreatment of Group A was $19.96 \pm 2.1 \mathrm{~kg}$ and that of Group B was $20.25 \pm 2.54 \mathrm{~kg}$. The mean difference between both groups was $-0.29 \mathrm{~kg}$. There was no significant difference in the quadriceps muscle force between Group A and B pre-treatment $(p=0.8)$ (Table 5).

The mean \pm SD calf muscle force post-treatment of Group A was $29.6 \pm 2.39 \mathrm{~kg}$ and that of Group B was $25.78 \pm 2.59 \mathrm{~kg}$. The mean difference between both groups was $3.82 \mathrm{~kg}$. There was a significant increase in calf muscle force of Group A compared with that of Group B post-treatment ( $p=0.01)$ (Table 6).

The mean \pm SD quadriceps muscle force posttreatment of Group A was $29.7 \pm 1.79 \mathrm{~kg}$ and that of Group B was $26.18 \pm 3.39$. The mean difference between both groups was $3.52 \mathrm{~kg}$. There was a significant increase in quadriceps muscle force of Group A compared with that of Group B posttreatment $(p=0.02)$ (Table 6).

Table (3): Comparison between pre and post-treatment mean values of calf and quadriceps muscles force of Group A.

\begin{tabular}{|c|c|c|c|c|c|c|c|}
\hline $\begin{array}{l}\text { Muscle } \\
\text { force }(\mathrm{kg})\end{array}$ & $\begin{array}{c}\text { Pre } \\
\mathrm{X} \pm \mathrm{SD}\end{array}$ & $\begin{array}{c}\text { Post } \\
\mathrm{X} \pm \mathrm{SD}\end{array}$ & MD & $\begin{array}{c}\% \text { of } \\
\text { improvement }\end{array}$ & $\begin{array}{c}t- \\
\text { value }\end{array}$ & $\begin{array}{c}p- \\
\text { value }\end{array}$ & Sig. \\
\hline Calf & $20.48 \pm 1.86$ & $29.6 \pm 2.39$ & -9.12 & $44.53 \%$ & -12.11 & 0.0001 & $\mathrm{~S}+$ \\
\hline Quadriceps & $19.96 \pm 2.1$ & $29.7 \pm 1.79$ & -9.74 & $48.79 \%$ & -16.86 & 0.0001 & $\mathrm{~S}+$ \\
\hline $\begin{array}{ll}\mathrm{X} & : \text { Mear } \\
\mathrm{MD} & : \text { Mea } \\
p \text {-value } & : \text { Prob } \\
\mathrm{SD} \pm & : \text { Stan } \\
t \text {-value } & : \text { Paire } \\
\mathrm{S} & : \text { Sign }\end{array}$ & $\begin{array}{l}\text { Difference. } \\
\text { bility value. } \\
\text { ard Deviation. } \\
t \text {-value. } \\
\text { icant increase. }\end{array}$ & & & & & & \\
\hline
\end{tabular}


Table (4): Comparison between pre and post-treatment mean values of calf and quadriceps muscles force of Group B.

\begin{tabular}{|c|c|c|c|c|c|c|c|}
\hline $\begin{array}{l}\text { Muscle } \\
\text { force }(\mathrm{kg})\end{array}$ & $\begin{array}{c}\text { Pre } \\
\mathrm{X} \pm \mathrm{SD}\end{array}$ & $\begin{array}{c}\text { Post } \\
X \pm S D\end{array}$ & MD & $\begin{array}{c}\% \text { of } \\
\text { improvement }\end{array}$ & $\begin{array}{c}t- \\
\text { value }\end{array}$ & $\begin{array}{c}p- \\
\text { value }\end{array}$ & Sig. \\
\hline Calf & $21.01 \pm 2.78$ & $25.78 \pm 2.59$ & -4.77 & $22.7 \%$ & -44.9 & 0.0001 & $\mathrm{~S}+$ \\
\hline Quadriceps & $20.25 \pm 2.54$ & $26.18 \pm 3.39$ & -5.93 & $29.28 \%$ & -5.16 & 0.001 & $\mathrm{~S}+$ \\
\hline
\end{tabular}

Table (5): Comparison between pre-treatment mean values of calf and quadriceps muscles force of Group A and B.

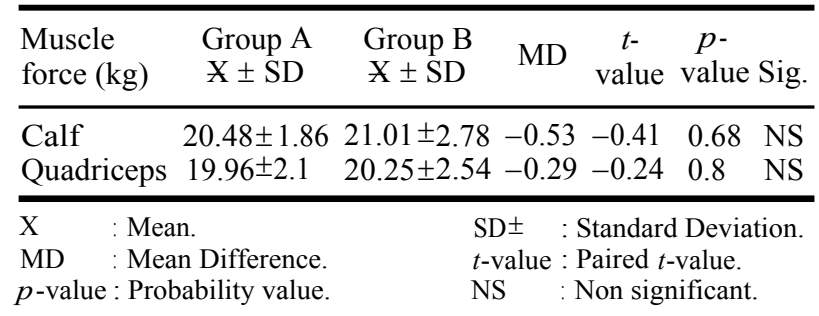

\section{Discussion}

This study was designed to test whether the combination of WBV and traditional physical therapy exercise program has any additional effect on knee extensors and ankle planter flexor muscles strength compared to an identical exercise program without vibration on patient with healed thermal burn. The results indicate that 8 weeks of combined WBV and traditional physical therapy exercise program increased muscle strength more than traditional physical therapy exercise program in the absence of vibrations. These strength measures illustrated that the whole body vibration increase lower limb strength after thermal burn, with significantly larger gains observed in calf and quadriceps muscles strength. Measurement done pre and post-treatment by hand held dynamometer and manual muscle test.

Whole body vibration training induced increase in leg muscle activity in male physical education students, the gastrocnemius is the closest muscle to the platform and thus the tonic vibration reflex is stronger and results in higher activation of the muscle [8]

The early gains in force-generating capacity have been attributed to neural factors, probably related to an increase in sensitivity of the stretch reflex, stimulation of Ia-afferents via the muscle spindle, resulting in facilitating homonymous amotor neurons. Whole Body Vibration (WBV) received a great deal of attention due to reports of enhanced physical performance. WBV may be an
Table (6): Comparison between post-treatment mean values of calf and quadriceps muscles force of Group A and $\mathrm{B}$.

\begin{tabular}{|c|c|c|c|c|c|c|}
\hline $\begin{array}{l}\text { Muscle } \\
\text { force }(\mathrm{kg})\end{array}$ & $\begin{array}{l}\text { Group A } \\
X \pm \text { SD }\end{array}$ & $\begin{array}{c}\text { Group B } \\
X \pm \text { SD }\end{array}$ & MD & $\begin{array}{c}t- \\
\text { value }\end{array}$ & $\begin{array}{c}p- \\
\text { value }\end{array}$ & Sig. \\
\hline Calf & $20.48 \pm 1.86$ & $21.01 \pm 2.78$ & -0.53 & -0.41 & 0.68 & NS \\
\hline Quadriceps & $19.96 \pm 2.1$ & $20.25 \pm 2.54$ & -0.29 & -0.24 & 0.8 & NS \\
\hline 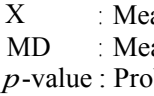 & bility value. & & $\begin{array}{l}\mathrm{D} \pm \\
\text { value } \\
\mathrm{S} \quad \mathrm{I} \\
\mathrm{S}\end{array}$ & $\begin{array}{l}\text { Paire } \\
\text { Non }\end{array}$ & ifican & \\
\hline
\end{tabular}

effective alternative to resistance training as WBV appeared to elicit neural changes [9].

Effects of Whole body vibration had shown improvement in knee extensor strength, vertical jump, chair-rising time, body balance, chronic back pain, and hip bone mineral density. The vertical jump height increased by $8.5 \%$ after four months of whole body vibration training. Furthermore, acute, while chronic WBV had shown no effect [10]

Whole Body Vibration (WBV) enhances muscle power and improve muscular performance. Practically, application enhances anaerobic power [11].

Whole-body vibration has been suggested to elicit a high degree of muscle activation. After three months of whole body vibration training, isometric and dynamic knee extensor strength improved by $16.6 \%$ and $9.0 \%$ respectively, whereas an equal number of moderate resistance training sessions induced similar gain $14.4 \%$ and $7.0 \%$ respectively. In a placebo-controlled study, knee extensor strength improvements following WBV were associated with reflex muscle activity and not the body-weight exercises. The current study also demonstrated improvements in knee extensor strength following WBV, yet these gains were significantly larger than those for a group performing the same exercises without vibration [6]

Issurin reports that the cumulative effect of WBV stimulus improves monosynaptic stretch reflexes induced by afferent signals from muscle 
spindles, as well as reducing the inhibiting impact of golgi tendon organs located at myotendinous junctions [12].

Despite the increasing scientific interest, the results of WBV interventions on muscular performance differ between studies. Two recent systematic reviews highlighted that gender, age, training status, and exercise protocol are moderators of the response to vibration exercise for strength and power development. The type of vibrating platform also seems to affect the training results. For chronic adaptations, like those investigated in our study, synchronous (vertical) platforms have been suggested to elicit a larger treatment effect than alternating (oscillating) platforms. Vibration frequencies between 35 and $40 \mathrm{~Hz}$ and peak-to peak displacements from 8 to $10 \mathrm{~mm}$ have shown to be the most effective for long-term strength and power adaptations [13].

\section{Conclusion:}

From the previous results and discussions, it could be concluded that Whole body vibration protocol in combination with a proper physical therapy exercise program improve leg muscle strength in subjects with thermal burn.

\section{References}

1- WATSON S.P.: "Soft tissue healing." In Touch, 104 (7): 2-9, 2003

2- SUMAN O.E., SPIES R.J., CELIS M.M., MLCAK R.P. and HERNDON D.N.: "Effects of a 12-week resistance exercise program on skeletal muscle strength in children with burn injuries". J. App. 1. Physio., 191: 1168-75, 2001.

3- ROHRER-MIRTSCHINK S., FORSTER N., GIOVANOLI P. and GUGGENHEIM M.: "Major burn injuries associated with Christmas celebrations: A 41-year experience from
Switzerland". Annals of burns and fire disasters, 28: 571, 2015.

4- KLEIN G.L.: "Disruption of bone and skeletal muscle in severe burns". Bone Research, 30: 28-150, 2015.

5- REES S.S., MURPHY A.J. and WATSFORD M.L.: "Effects of whole-body vibration exercise on lower-extremity muscle strength and power in an older population: A randomized clinical trial". Phys. Ther., 88 (4): 462-70, 2008.

6- DELECLUSE C., ROELANTS M. and VERSCHUEREN S.: "Strength increase after whole-body vibration compared with resistance training". Medicine and Science in Sports and Exercise, 35 (6): 1033-41, 2003.

7- RITTWEGER J.: "Vibration as an exercise modality: How it may work, and what its potential might be". Eur. J. Appl. Physiol., 108 (5): 877-904, 2010.

8- ROELANTS M., VERSCHUEREN S.M., DELECLUSE C., LEVIN O. and STIJEN V.: "Whole-body vibration induced increase in leg muscle activity during different squat exercises". Journal of Strength and Conditioning Research, 20 (1): 124-9, 2006.

9- ROELANTS M., DELECLUSE C. and VERSCHUEREN S.M.: "Whole-body-vibration training increases kneeextension strength and speed of movement in older women". J. Am. Geriatr. Soc., 52 (6): 901-8, 2004.

10- TORVINEN S., KANNUS P., SIEVANEN H. and JARVINEN T.A.: "Effect of four-month vertical whole body vibration on performance and balance". Medicine and Science in Sports and Exercise, 34 (9): 1523-8, 2002.

11- COCHRANE D.J. and STANNARD S.R.: "Acute whole body vibration training increases vertical jump and flexibility performance in elite female field hockey players". Br. J. Sports Med., 39 (11): 860-5, 2005.

12- ISSURIN V.B.: "Vibrations and their applications in sport. A review". J. Sports Med. Phys. Fitness., 45: 324-36, 2005.

13-MARIN P.J. and RHEA M.R.: "Effects of vibration training on muscle power: A meta-analysis". J. Strength Cond. Res., 24 (3): 871-8, 2010. 


\section{فاعلية إهتزاز الجسم كله على تقوية العضلة الرباعية العزية وعضلة الساق بعد الحروق كانه}

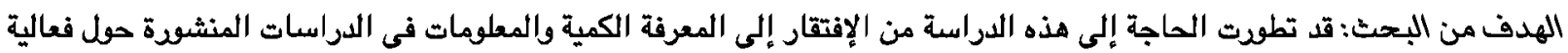

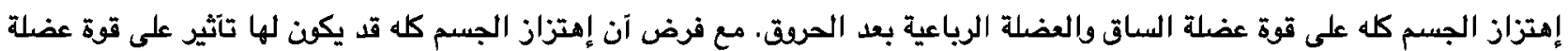

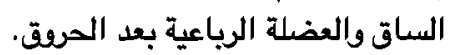

مواد وآساليب العلاج: بدآ العلاج فودا بعد إلتئام الجرح. وكان ثلاثقن مريضا يعانون من حرق الدرجة الثانية فى الطرف السفلى مع مساحة

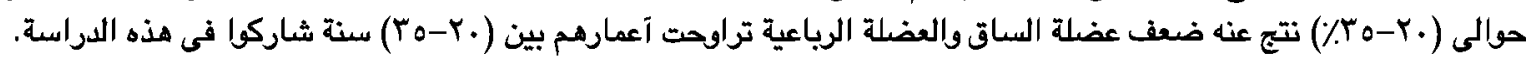
وقد آجريت الدراسة خلال الفترة ما بين شهرى مارس ويوليه IV T في هستشفى ومستشفى الندى. وتم تصنيفها عشوائيا إلى مجموعتين متساويتين:

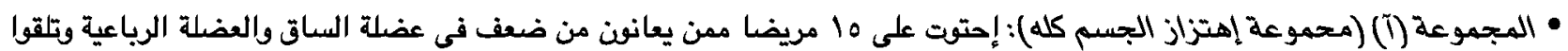

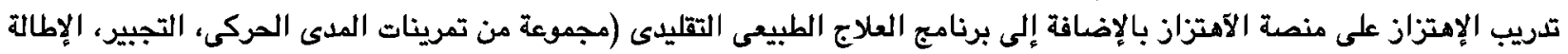



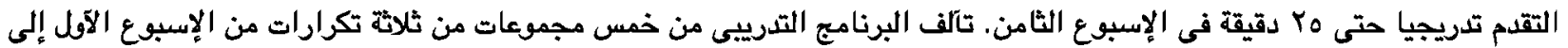

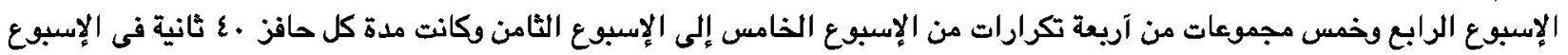

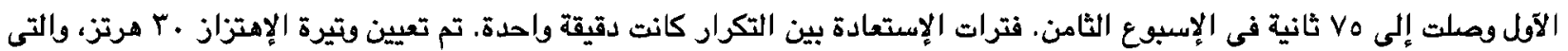

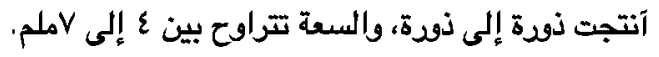

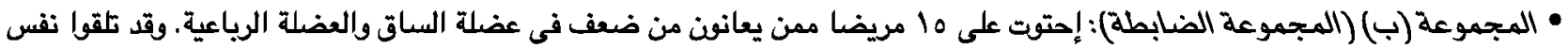



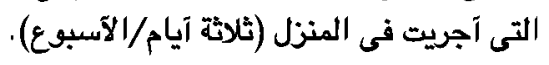

تم تقييم جميع المرضى قبل بدء برنامج العلاج ثم بعد نهاية ثمان آسابيع بإستخدام قياسات المقرى باليد وإختبار العضلة اليدوى لقياس

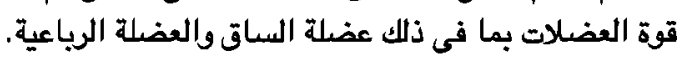

$$
\text { تم مقارنة البيانات التى تم جمعها (قبل وبعد العلاج) إحصائيا وتحليلها. }
$$

آظهرت المجموعتان تصسنا مختلفا فى قوة عضلة الساق والصضلة الرياعية، ولكن تم تسجيل فرق تصسن ذو دلالة إحصائية بين المجموعتين 